\title{
$\mathrm{HF}$ 크리닝 처리한 코발트실리사이드 버퍼층 위에 $\mathrm{PA}-\mathrm{MBE}$ 로 성장시킨 $\mathrm{GaN}$ 의 에피택시
}

\author{
하준석 ${ }^{1}$, 장지호 ${ }^{2}$, 송오성 ${ }^{3^{*}}$ \\ ${ }^{1}$ 전남대학교 응용화학공학부 \\ ${ }^{2}$ 한국해양대학교 나노반도체공학과 \\ ${ }^{3}$ 서울시립대학교 신소재공학과
}

\section{GaN Epitaxy with PA-MBE on HF Cleaned Cobalt-silicide Buffer Layer \\ Jun-Seok Ha ${ }^{1}$, Ji-Ho Chang ${ }^{2}$ and Ohsung Song ${ }^{3^{*}}$ \\ ${ }^{1}$ Faculty of Applied Chemical Engineering, Chonnam National University \\ ${ }^{2}$ Department of Nano Semiconductor Engineering, Korea Maritime University \\ ${ }^{3}$ Department of Materials Science and Engineering, University of Seoul}

\begin{abstract}
요 약 실리콘 기판에 $\mathrm{GaN}$ 에피성장을 확인하기 위해, $\mathrm{P}$ 형 $\mathrm{Si}(100)$ 기판 전면에 버퍼층으로 $10 \mathrm{~nm}$ 두께의 코발트실 리사이드를 형성시켰다. 형성된 코발트실리사이드 층을 HF로 크리닝하고, PA-MBE (plasma assisted-molecular beam epitaxy)를 써서 저온에서 $500 \mathrm{~nm}$ 의 $\mathrm{GaN}$ 를 성막하였다. 완성된 $\mathrm{GaN}$ 은 광학현미경, 주사탐침현미경, TEM, HR-XRD를 활용하여 특성을 확인하였다. $\mathrm{HF}$ 크리닝을 하지 않은 경우에는 $\mathrm{GaN}$ 에피택시 성장이 진행되지 않았다. $\mathrm{HF}$ 크리닝을 실시한 경우에는 실리사이드 표면의 국부적인 에칭에 의해 $\mathrm{GaN}$ 성장이 유리하여 모두 $\mathrm{GaN} 4 \mu \mathrm{m}$ 정도의 두께를 가진 에피택시 성장이 진행되었다. $\mathrm{XRD}$ 로 $\mathrm{GaN}$ 의 <0002> 방향의 결정성 (crsytallinity)을 $\omega$-scan으로 판단한 결과 $\mathrm{Si}(100)$ 기판의 경우 2.7 도를 보여 기존의 사파이어 기판 정도로 우수할 가능성이 있었다. 나노급 코발트실리사이드를 버퍼로 채용하여 $\mathrm{GaN}$ 의 에피성장이 가능할 수 있었다.
\end{abstract}

\begin{abstract}
We fabricated $10 \mathrm{~nm}$-thick cobalt silicide $\left(\mathrm{CoSi}_{2}\right)$ as a buffer layer on a p-type $\mathrm{Si}(100)$ substrate to investigate the possibility of $\mathrm{GaN}$ epitaxial growth on $\mathrm{CoSi}_{2} / \mathrm{Si}(100)$ substrates. We deposited $500 \mathrm{~nm}-\mathrm{GaN}$ on the cobalt silicide buffer layer at low temperature with a PA-MBE (plasma assisted-molecular beam epitaxy) after the $\mathrm{CoSi}_{2} / \mathrm{Si}$ substrates were cleaned by $\mathrm{HF}$ solution. An optical microscopy, AFM, TEM, and HR-XRD (high resolution X-ray diffractometer) were employed to determine the GaN epitaxy. For the GaN samples without HF cleaning, they showed no GaN epitaxial growth. For the GaN samples with HF cleaning, they showed $4 \mu \mathrm{m}$-thick GaN epitaxial growth due to surface etching of the silicide layers. Through XRD $\omega$-scan of $\mathrm{GaN}<0002>$ direction, we confirmed the cyrstallinity of GaN epitaxy is $2.7^{\circ}$ which is comparable with that of sapphire substrate. Our result implied that $\mathrm{CoSi}_{2} / \mathrm{Si}(100)$ substrate would be a good buffer and substrate for $\mathrm{GaN}$ epitaxial growth.
\end{abstract}

Key Words : GaN, Epitaxy, PA-MBE, Cobalt Silicide Buffer, Silicon Substrate

1. 서론

최근의 $\mathrm{GaN}$ 을 이용한 LED (light emitting diode)는 새 로운 조명소자로 에너지와 환경면에서 각광 받고 있다.
LED 공정에는 pn junction의 효율을 높이고 누설전류 (leakage current)를 줄여 효율성을 높이기 위해 양질의 $\mathrm{GaN}$ 층의 에피텍시 성장이 필수적이다. $\mathrm{GaN}$ 에피성장을 위해서는 가장 이상적으로는 $\mathrm{GaN}$ 단결정 기판을 사용하

이 논문은 2009년도 서울시립대학교 교내학술연구비에 의하여 연구되었음.

*교신저자 : 송오성(songos@uos.ac.kr)

접수일 09년 06월 16일 수정일 (1차 09년 11월 14일, 2차 10년 01월 15일)

게재확정일 10 년 02 월 24일 
는 것이나, 현재 bulk GaN의 단결정 제조 기술이 확보되 지 않아 차선책으로 이종기판인 사파이어 또는 $6 \mathrm{H}-\mathrm{SiC}$ 기판이 사용되고 있다. [1]

궁극적으로 경제적인 대량생산을 위해서는 기존 반도 체 공정에서 검증된 대구경 실리콘 기판의 채용이 필요 하다 할 수 있다. 그러나 실리콘 기판은 wurtzite 구조의 $\mathrm{GaN}$ 과 $-17 \%$ 의 격자간 상수 차이와 $115 \%$ 에 이르는 열 팽창계수 차이가 있어, 직접 실리콘 기판 위에 $\mathrm{GaN}$ 을 성 막하기에는 많은 어려움이 있다. 이를 위하여 두 물질사 이에 적절한 버퍼층을 형성시켜 $\mathrm{GaN}$ 층을 성장하는 연 구가 많이 진행되고 있다. 최근 이를 위하여 여러 가지 방법이 적용되고 있는데, 버퍼층으로서 $\mathrm{GaN}$ 와 같은 wurtzite 결정구조를 가진 $\mathrm{AlN}$ 나 $\mathrm{ZnO}$ 등의 재료가 사용하 여 $\mathrm{GaN}$ 층과의 격자간 상수 차이와 열스트레스를 감소 시키는 방법이나, 기판에 의도적으로 패턴을 도입하여 특 정 면방향의 $\mathrm{GaN}$ 층을 성장시키는 방법, 그리고 성장시 $\mathrm{GaN}$ 버퍼층을 먼저 성장시킨 후 이를 버퍼로 작용시켜 고온 후막 $\mathrm{GaN}$ 층을 만드는 방법이 2단계 성장법 등이 연구되고 있다.

J. X, Zhang 등[2]은 $\mathrm{Si}(111)$ 기판에 $\mathrm{AlN}$ 버퍼층을 채 용하여 기존의 $\mathrm{AlN} /$ 사파이어기판 조합과 비슷한 정도의 $\mathrm{GaN}$ 에피 성장을 확보한 보고를 하였다. $\mathrm{ZrN} / \mathrm{AlN}$ 복합 버퍼층을 이용한 연구[3]와 $\mathrm{ScN}$ 과 같은 새로운 나이트라 이드 화합물[4] 및 $\mathrm{SiN}[5]$ 을 이용한 다양한 시도가 진행 되고 있으나 아직 사파이어 기판과 비교할 때 결정성 향 상 및 결정성장법의 단순화 등의 문제가 존재한다. 또한 패턴이 형성된 miscut $\mathrm{Si}$ 기판 $\left(7^{\circ} \mathrm{off}\right)$ 을 이용한 $\mathrm{GaN}$ 성 장 연구[6,7]등 버퍼층 대신 실리콘의 다양한 면 방향을 이용하여 $\mathrm{GaN}$ 에피성장을 이루려는 노력도 있지만 아직 초기단계이다.

이러한 여러 가지 버퍼층 소재 중에서 코발트 실리사 이드가 가능하다. 실리사이드 (silicide)는 실리콘과 천이 금속의 중간상으로 현대의 상용화된 대부분의 MOSFET (metal oxide semiconductor field emission transistor) 소자 의 접촉 저항을 줄이고, 배선층의 확산 방지막, 메탈 컨택 에치 (metal contact etch)시의 stopping layer로서의 역할 을 위해 개발되었다.

실리콘 기판위에 직접 금속층을 성막하고 실리사이드 화 반응을 시키는 열처리에 의해 실리사이드를 제작하는 살리사이드 (self-aligned silicide) 공정을 통하여 구현되 는 기존의 저저항 특성을 가지는 실리사이드로는 $\mathrm{WSi}_{2}$, $\mathrm{TiSi}_{2}, \mathrm{CoSi}_{2}, \mathrm{NiSi}$ 등이 있다. 특히 단결정 실리콘 기판과 epitaxy를 이루는 실리사이드로는 $\mathrm{CoSi}_{2}, \mathrm{VSi}_{2}, \mathrm{CrSi}_{2}$, $\mathrm{MoSi}_{2}, \mathrm{WSi}_{2}$ 등이 가능하다. 실리사이드는 실리콘기판과 의 에피텍시가 용이하여 $\mathrm{GaN}$ 과의 격자간 불일치와 열팽
창계수 차이를 줄여주어 $\mathrm{GaN}$ 의 에피텍시 성장에 버퍼역 할을 함과 동시에, 최종 실리사이드가 저저항을 가진 도 전체라서 궁극적으로 전극체 역할을 할 수 있어서 최근 에 개발되는 수직형 LED 제조에 공정 단순화를 제공할 수 있는 장점이 있다. 또한 실리콘 기판과 자립형 $\mathrm{GaN}$ 층을 분리하는데 필요한 선택적인 에칭이 용이할 것이 기대된다. 나노급 $\mathrm{CoSi}_{2}$ 는 이미 제조공정이 잘 알려져 있 고 고온안정성이 우수하지만 $\mathrm{HF}$ 크리닝에 따른 표면변 화는 잘 알려져 있지 않다 $[8,9]$

PA-MBE (plasma-assisted molecular beam epitaxy)는 초고진공에서 원자단위의 정밀성막이 가능한 기자재로 본 연구에서는 플라즈마에 의해 성막속도가 향상된 장비 를 채용하여 성막하였다. 기존의 $\mathrm{GaN}$ 를 제작하는 후막용 장비인 HVPE (hydride vapor phase epitaxy)가 1000도 이 상의 고온에서 성장하는데 비해서 800 도 정도의 비교적 저온에서 성장이 가능한 장점이 있다. [10]

본 연구에서는 실리콘 기판 위에 버퍼층으로 나노급 코발트실리사이드를 만들고 다시 실리사이드 층을 불산 으로 크리닝 처리한 후 $\mathrm{PA}-\mathrm{MBE}$ 로 $\mathrm{GaN}$ 층을 성막한 후 HVPE로 에피성장을 진행함으로써 실리콘 기판에 $\mathrm{GaN}$ 의 에피성장 가능성을 확인하여 보았다.

\section{2. 실험방법}

실험에 사용된 기판은 직경 $100 \mathrm{~mm}$, 두께 $500 \mu \mathrm{m}$ 의 p-type(100) 단결정 실리콘 웨이퍼로서 크리닝이 완료된 기판은 자연 산화막이 형성되기 전에 $1 \mathrm{~nm}$ 두께의 코발트 금속을 전자총 증착기 (e-gun evaporator)로 증착시켜 최 종적으로 $1 \mathrm{~nm}-\mathrm{Co} / \mathrm{Si}$ 구조의 시편을 준비하였다.

완성된 시편들은 $10^{-3}$ torr의 진공에서 7쌍의 할로겐 램프로 구성된 $\mathrm{RTA}$ 를 활용하여 $800^{\circ} \mathrm{C}$ 의 조건에서 40 초 간 열처리하여 실리사이드가 생성되도록 하였다. 열처리 가 완료된 시편들은 잉여금속을 제거하기 위해서 $80^{\circ} \mathrm{C}$ 에 서 $30 \mathrm{vol} \%$-황산에 10 분간 담가 처리하였다. 완성된 기 판은 $1 \times 1 \mathrm{~cm}^{2}$ 크기로 다이아몬드 소우 (saw)로 다이싱하 여 이후 한 조각을 증착장비에 장입하여 $\mathrm{GaN}$ 층을 성장 시키기 용이하도록 하였다.

준비된 시료는 $\mathrm{MBE}$ 장입 전에 아세톤, 메탄올, 초순 수 순으로 각 10 분간 유기세척을 실시하였고, 세척 후 장 입직전에 $10 \% \mathrm{HF}$ 수용액에 30 초간 침지하고 초순수로 세척하는 공정을 3 회 반복하여 장입하였다. 비교를 위해 서 $\mathrm{HF}$ 크리닝을 실시하지 않은 시편도 같이 장입하였다.

$\mathrm{GaN}$ 를 성막하기 위해 $\mathrm{PA}-\mathrm{MBE}$ 장비를 활용하였다. $\mathrm{Ga}$ 의 공급에는 Knudsen cell 을 사용하였고, $\mathrm{N}$ 의 공급은 
플라즈마 소스를 사용하였다. 성장률은 시간당 $500 \mathrm{~nm}$ 정 도로 제어되었으며, 장입된 기판은 $850^{\circ} \mathrm{C}$ 에서 30 분간의 열처리 후, 기판 온도 $500^{\circ} \mathrm{C}$ 에서 저온에서 버퍼층을 50 $\mathrm{nm}$ 성장하고 연속하여 기판 온도 $800^{\circ} \mathrm{C}$ 에서 유지하여 $230 \mathrm{~nm}$ 로 성장을 실시하였다.

PA-MBE로 에피성장이 확인된 시료에 대해서 HVPE 로 $1040^{\circ} \mathrm{C}$ 에서 20 분간 고온 $\mathrm{GaN}$ 성장을 실시하여 다시 $4 \mu \mathrm{m}$ 의 후막 $\mathrm{GaN}$ 을 성막 하였다.

완성된 박막은 박막 진행에 따라 광학현미경, 주사전 자현미경, 주사탐침현미경과 $\mathrm{HR}-\mathrm{XRD}$ 를 활용하여 미세 구조와 결정성을 확인하였다.

Olympus사의 UV 광원 기능이 부가된 광학 현미경을 활용하여 500 배까지 관찰하였다. 광학현미경을 활용하면 거시적인 표면미세구조와 특히 $\mathrm{GaN}$ 층은 통상 $\mathrm{UV}$ 광에 대해 형광색을 띠므로 UV 광원모드로 쉽게 형광색의 확 인과 국부적인 표면 색 변화에 따라 스트레스에 따른 밴 드갭의 변화를 간접적으로 확인하였다.

SEIKO사의 SII AFM의 컨택 모드를 사용하여 $\mathrm{GaN}$ 층 의 표면조도와 표면 이미지를 측정하였다.

$\mathrm{TEM}$ (transmission electron microscope) 관찰을 위한 시편은 일반적인 수직단면 관찰용 TEM 시편 제작방법 [11]을 이용하여 제작한 후 TEM을 써서 $\mathrm{GaN}$ 에피택시 부의 bright field image를 찍어서 실리사이드 층의 두께 와 미세구조를 확인하였다.

고해상도 X선회절 분석 장치를 사용하여 상분석과 결 정성을 해석하였다. $\mathrm{CuKa}(\lambda=1.5406 \AA)$ 선을 이용하여 2 $\Theta=20 \sim 100^{\circ}$ 까지의 wide scan을 이용하여 $\mathrm{GaN}$ 상의 존재 유무를 확인하였고, $\Theta=17.3^{\circ}$ 부근의 $\mathrm{GaN}(0002)$ 면의 오 메가 $(\omega)$ scan을 실시하여 결정성 (crystallinity)을 정량적 으로 판단하였다.

\section{3. 실험결과 및 토의}

육안분석을 통하여 완성된 $\mathrm{CoSi}_{2} / \mathrm{Si}(100)$ 기판은 $\mathrm{CoSi}_{2}$ 층이 실리콘 기판과 비슷한 정도의 광택도를 유지하면서 더욱 진한 진회색의 표면을 보여 증착 전과 비교하여 간 접적으로 $\mathrm{CoSi}_{2}$ 층의 존재를 확인할 수 있었다. $\mathrm{GaN}$ 층 은 통상 무색투명한 것으로 알려져 있으나 하지층이 불 투명한 $\mathrm{CoSi}_{2} / \mathrm{Si}(100)$ 기판이므로 성막직후에 표면색상의 변화로 $\mathrm{GaN}$ 층의 존재를 육안으로도 확인이 가능하였다.

그림 1 에는 $\mathrm{HF}$ 크리닝 전후의 코발트 실리사이드 층의 $\mathrm{AFM}$ 이미지를 나타내었다. (a)는 $\mathrm{HF}$ 크리닝 전의 $\mathrm{Si}(100)$ 위의 코발트실리사이드가 형성된 직후의 표면이미지로서 $2 \mu \mathrm{m}$ 정도의 결정립을 가지고 있는 구조를 보이고 있다. (b)에 나타낸 불산 처리 후의 표면형상은 코발트실리사이 드의 특정 부분들이 선택적으로 에칭되어 $0.5 \mu \mathrm{m}$ 정도의 피치를 가진 결정립계를 보이고 있다. 결과적으로 $\mathrm{HF}$ 처 리에 따른 에칭으로 표면조도 rms (root mean square)는 $\mathrm{HF}$ 크리닝에 따라 1.5 에서 $2.0 \mathrm{~nm}$ 로 증가하였으며, 이러한 표면조도의 증가와 결정립의 미세화는 궁극적으로 표면 적을 넓혀 후속 $\mathrm{GaN}$ 의 성장에 유리할 것으로 기대되었 다. 일반적으로 실리사이드는 $\mathrm{HF}$ 에도 내식성이 뛰어난 것으로 알려졌으나 나노급 코발트실리사이드는 30 초간 의 에칭에도 식각이 발생하여 버퍼층으로서 표면형상 조 절을 위해 $\mathrm{HF}$ 크리닝 처리가 가능함을 보였다.

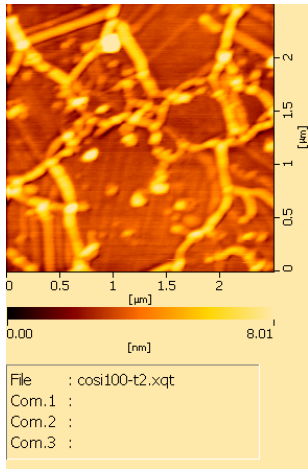

(a)

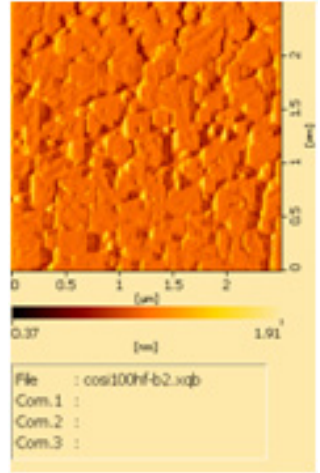

(b)
[그림 1] 코발트실리사이드의 AFM 이미지:

(a) $\mathrm{CoSi}_{2} / \mathrm{Si}(100), \mathrm{HF}$ 크리닝 처리, (b) $\mathrm{CoSi}_{2} / \mathrm{Si}(100), \mathrm{HF}$ 크리닝 미처리.

그림 2에는 $\mathrm{HF}$ 크리닝 처리 유무에 따라 PA-MBE로 $\mathrm{GaN}$ 성막한 시편들의 $\mathrm{GaN}$ 층을 광학현미경으로 관찰한 이미지를 나타내었다. (a)에 나타낸 코발트실리사이드 층 을 $\mathrm{HF}$ 처리를 하지 않고 $\mathrm{GaN}$ 을 성막한 시편은 모두 육안 으로도 표면광택이 없었고 불균일한 표면을 확인할 수 있었고 사진과 같이 어둡게 나타난 부분만이 부분적으로 $\mathrm{GaN}$ 가 성막되었음에 근거하여 $\mathrm{GaN}$ 의 에피성장이 진행 되지 않았음을 알 수 있었다.

반면 그림 2(b)의 $\mathrm{HF}$ 처리를 실시하고 진행한 $\mathrm{CoSi}_{2} / \mathrm{Si}(100)$ 기판의 $\mathrm{GaN}$ 은 고배율 광학현미경에도 매 우 균일한 표면 이미지를 보였다. 사진에서 검은 부분은 $\mathrm{MBE}$ 공정에서 $\mathrm{Ga}$-과잉상이 출현하여 금속 $\mathrm{Ga}$ 이 응집되 어 나타난 것이다. $\mathrm{Ga}$ 의 존재와 $\mathrm{GaN}$ 의 존재는 광학현미 경의 $\mathrm{UV}$ 모드로 $\mathrm{GaN}$ 의 황색 형광특성을 이용하여 확인 하였다. 


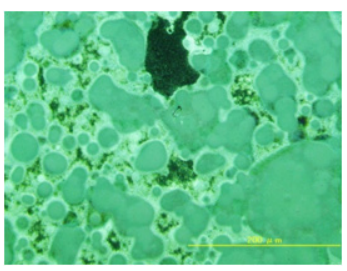

(a)

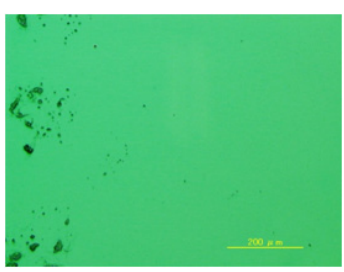

(b)
[그림 2] PA-MBE로 성막한 $\mathrm{GaN}$ 층의 광학이미지: (a) $\mathrm{GaN} / \mathrm{CoSi}_{2} / \mathrm{Si}(100), \mathrm{HF}$ 크리닝 미처리, (b) $\mathrm{GaN} / \mathrm{CoSi}_{2} / \mathrm{Si}(100), \mathrm{HF}$ 크리닝 처리.

그림 3에는 $\mathrm{HF}$ 크리닝을 실시하고 난 후 성장시킨 $\mathrm{GaN} / \mathrm{CoSi}_{2} / \mathrm{Si}(100)$ 구조의 $\mathrm{GaN}$ 층의 표면 조도와 결정립 크기를 확인한 $\mathrm{AFM}$ 이미지이다. 평균 결정립크기가 355 $\mathrm{nm}$ 였고 표면조도 $\mathrm{rms}$ 가 $1.5 \mathrm{~nm}$ 로 매우 평탄하였다. 이러 한 결과는 동일한 $\mathrm{PA}-\mathrm{MBE}$ 공정 조건으로 제작된 $\mathrm{AlN}$ 버퍼층/(0001) 사파이어 기판 위에 성장시킨 $\mathrm{GaN}$ 가 195 $\mathrm{nm}$ 정도의 결정립 크기를 보이고 표면조도 $\mathrm{rms}$ 도 $2.4 \mathrm{~nm}$ 임을 비교하여 코발트실리사이드/실리콘 기판도 기존의 사파이어 기판과 비슷한 정도의 표면조도와 결정립 성장 을 가지고 $\mathrm{GaN}$ 에피 성장에 활용될 수 있음을 의미하였다.

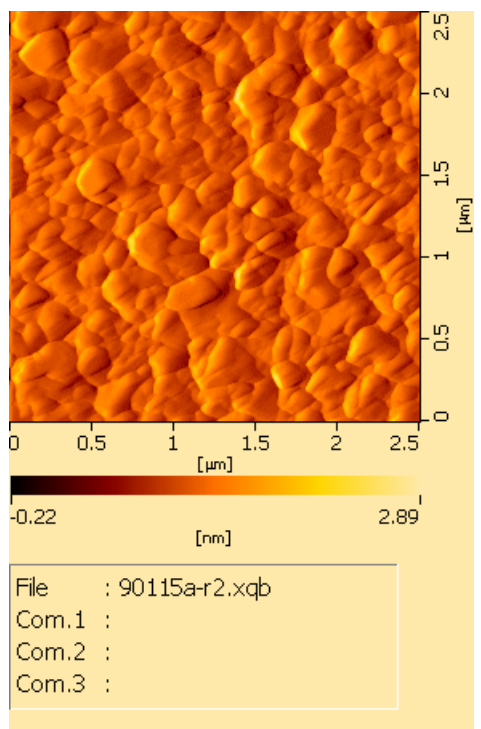

[그림 3] $\mathrm{HF}$ 크리닝 처리 후 성장시킨 $\mathrm{GaN} / \mathrm{CoSi}_{2} / \mathrm{Si}(100)$ 구조의 $\mathrm{GaN}$ 층의 $\mathrm{AFM}$ 이미지.

그림 4에는 $\mathrm{CoSi}_{2} / \mathrm{Si}$ 기판 위에 형성된 $\mathrm{GaN}$ 층의 TEM 수직단면 이미지를 나타내었다. 약 $10 \mathrm{~nm}$ 두께의 $\mathrm{CoSi}_{2}$ 위에 평균 $4.43 \mu \mathrm{m}$ 두께의 $\mathrm{GaN}$ 에피택시 층이 형성되었 다. $\mathrm{CoSi}_{2}$ 와 $\mathrm{GaN}$ 경계면에서 $\mathrm{GaN}$ 성장방향으로 약 55 $\mathrm{nm}$ 두께까지는 $\mathrm{GaN}$ 에피택시 층이 일정한 성장방향 없 이 무질서하게 성장하였으나, $55 \mathrm{~nm}$ 이후부터는 얇은 주 상정 모양의 $\mathrm{GaN}$ 에피택시 층이 경계면에 수직한 방향 으로 등축 성장하여, 약 $225 \mathrm{~nm}$ 부터는 넓은 폭의 결정립 을 가진 $\mathrm{GaN}$ 에피택시 층이 성장하였음을 확인하였다. 또한 좌상단에 나타낸 $\mathrm{SADP}$ 는 단결정화된 $\mathrm{GaN}$ 의 패턴 을 보여 $\mathrm{GaN}$ 에피택시 층의 존재를 직접적으로 증명하 고 있다.

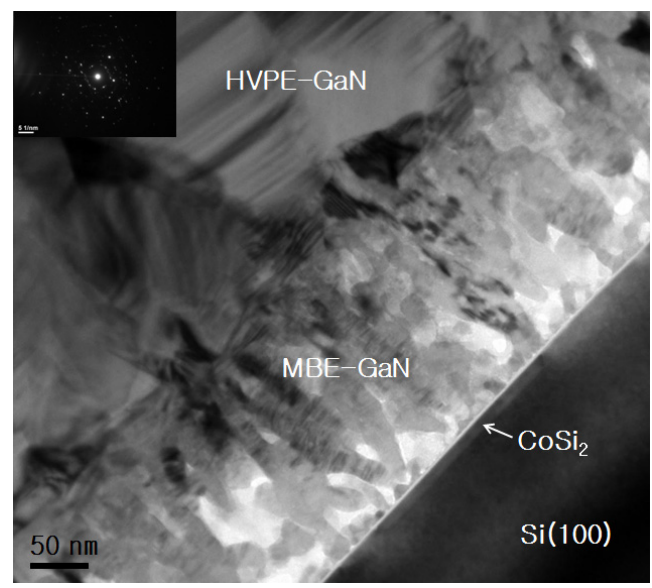

[그림 4] $\mathrm{CoSi}_{2}$ 기판 위에 형성된 $\mathrm{GaN}$ 층의 $\mathrm{TEM}$ 수직단 면 이미지.

그림 5 에는 $\mathrm{CoSi}_{2} / \mathrm{Si}$ 기판 위에 형성된 $\mathrm{GaN}$ 층의 (0002) 방향의 결정성 (crystallinity)을 XRD의 $\omega$-scan에 의해 정량적으로 확인한 결과를 나타내었다. $\mathrm{Ga}(0002)$ 방향의 $\Theta=17.3^{\circ}$ 에서의 반가폭으로 결정성을 판단한 결과 $2.7^{\circ}$ 이었다. 동일한 공정으로 $\mathrm{AlN} /$ 사파이어 기판에 성장 시킨 결정성이 $1.4^{\circ}$ 임에 비추어 공정조건을 개선하면 충 분히 우수한 결정성을 확보할 수 있음을 의미하였다.

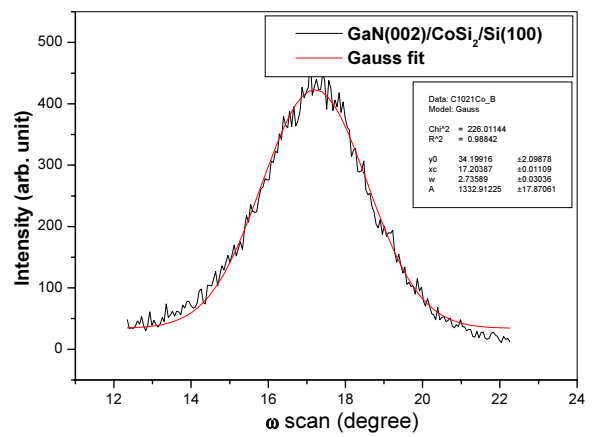

[그림 5] $\mathrm{CoSi}_{2}$ 기판 위에 형성된 $\mathrm{GaN}$ 층의 (0002) 방향의 $\omega$-scan 상분석. 


\section{4. 결론}

(100)면지수의 실리콘 기판에 형성된 나노급 두께의 코발트실리사이드를 버퍼층을 $\mathrm{HF}$ 로 크리닝 처리 유무에 따라 PA-MBE를 활용하여 $\mathrm{GaN}$ 의 에피 성장을 진행하였 다. 코발트실리사이드를 HF에 크리닝한 경우 코발트 실 리사이드층의 국부적인 표면에칭이 발생하였고 이러한 현상이 $\mathrm{GaN}$ 의 에피성장에 도움을 주었다. 성장된 $\mathrm{GaN}$ 층 의 결정성은 TEM과 XRD $\omega$-scan 으로 확인한 결과 기존 의 사파이어/AIN 기판 정도로 우수할 수 있었다.

\section{참고문헌}

[1] F. Dwikusuma, J. Mayer, T. F. Kuech, "Nucleation and initial growth kinetics on $\mathrm{GaN}$ on sapphire substrate by hydride vapor phase epitaxy", J. Cryst. Growth 258, (2003) 65.

[2] J. X, Zhang, Y. Qu, Y. Z. Chen, A. Uddin, Shu Yuan, "Structural and optical characterization of $\mathrm{GaN}$ epilayers grown on $\mathrm{Si}(111)$ substrates by hydrid vapor- phase epitaxy", J. Cryst. Growth 282, (2005) 137.

[3] M. H. Oliver, J. L. Schroeder, D. A. Ewoldt, I. H. Wildeson, V. Rawat, R. Colby, P. R. Cantwell, E. A. Stach, T. D. Sand, "Organometallic vapor phase epitaxial growth of $\mathrm{GaN}$ on $\mathrm{ZrN} / \mathrm{AlN} / \mathrm{Si}$ substrates", Appl. Phys. Lett. 93, (2008) 023109.

[4] M. A. Moram, S. V. Novikov, A. J. Kent, C. Norenberg, C. T. Foxon, C. J. Humphreys, "Growth of epitaxial thin films of scandium nitride on 100-oriented silicon", J. Cryst. Growth 310, (2008) 2746.

[5] E. Arslan, M. K. Ozturk, S. Ozcelik, E. Oabay, "The effect of $\mathrm{Si}_{\mathrm{x}} \mathrm{N}_{\mathrm{y}}$ interlayer on the quality of $\mathrm{GaN}$ epitaxial layers grown on $\mathrm{Si}(111)$ substrates by MOCVD", Current Appl. Phys. 9, (2009) 472.

[6] T. Hikosaka, T. Narita, Y. Honda, M. Yamaguchi, N. Sawaki, Appl. Phys. Lett. 84, (2004) 4717

[7] T. Hikosaka, Y. Honda, M. Yamaguchi, N. Sawaki, J. Appl. Phys. 101, (2007) 103513.

[8] D. Mangelinck, J. Y. Dai, J. S. Pan and S. K. Lahiri, Appl. Phys. Lett. 75, (1999) 1736.

[9] K. Maex, Mater. Sci. Engin. R11, (1993) 53.

[10] J. S. Park, S. K. Hong, T. Minegishi, I .H. Im. S. H. Park, T. Hanada, J. H. Chang, M. W. Cho, T. Yao, "The high quality $\mathrm{ZnO}$ growth on $\mathrm{c}-\mathrm{Al}_{2} \mathrm{O}_{3}$ substrate with $\mathrm{Cr}_{2} \mathrm{O}_{3}$ buffer layer using plasma-assisted molecular beam epitaxy", Appl. Surf. Sci. 254, (2008) 7786.

[11] D. B. Williams, C. B. Carter, Transmission Electron Microscopy Basics I, 1st ed., P.152-170, Plenum Press,
NewYork, U.S.A. (1996).

[12] M. A. Sanchez-Garcia, E. Calleja, E. Monroy, F. J. Sanchez, F. Calle, E. Munoz, R. Beresford, "The effect of the III/V ratio and substrate temperature on the morphology and properties of GaN- and AlN-layers grown by molecular beam epitaxy on $\mathrm{Si}(111) "$, J. Cryst. Growth 183, (1998) 23.

\section{하 준 석(Jun-Seok Ha)}

[정회원]

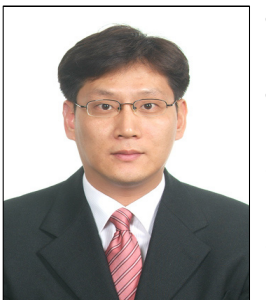

- 1997년 2월 : 홍익대학교 금속재 료공학과 (공학사)

- 1999년 2월 : 서울대학교 재료공 학부 (공학석사)

- 2002년 8월 : 서울대학교 재료공 학부 (공학박사)

- 2010년 3월 현재 : 전남대학 교 응용화학공학부 조교수

<관심분야>

화합물반도체재료, 발광다이오드

장 지 호(Ji-Ho Chang)

[정회원]

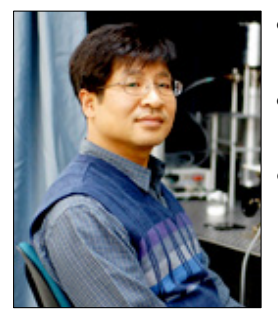

- 1991년 2월 인하대학교 전자공 학과 (공학사)

- 2001년 3월 Tohoku 대학 대학원 응용물리학과 (공학박사)

- 2003년 2월 현재 : 한국해양 대학교 나노반도체공학과 부교 수

<관심분야>

화합물반도체재료, 발광다이오드

송 오 성(Oh-sung Song)

[정회원]

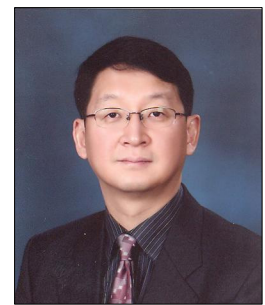

- 1987년 2월 :서울대학교 금속공 학과 (공학사)

- 1989년 2월 : 서울대학교 금속공 학과 (공학석사)

- 1994년 5월 : MIT 재료공학과 (공학박사)

- 1997년 9월 현재 : 서울시립 대학교 신소재공학과 교수

<관심분야>

반도체 재료, 자성 재료, 보석재료 